best-informed members of the medical profession. It makes mention of particulars required in connexion with the disease and amongst others "post-choleraic fever." This was certainly a remarkable phase in the disease, although its presence was exceptional, and it was accompanied by a rash; models of this eruption in wax are now to be seen in the museum of Guy's Hospital. It had been observed in more than one of the epidemics. As regards the committee meeting at the Privy Council Office, Dr. Bristowe and myself were chosen to do the practical work-that is, to make a special study of the disease as regards causes, contagion, treatment, \&c. Probably I might have been chosen because of my knowledge of post-mortem appearances, having made several examinations of the bodies after death. The appearances I have described in my work on "Pathological Anatomy," the most notable being that of the intestines, which instead of being distended with gas lay in a small compass, feeling sodden, doughy, and flabby. I should regard this remarkable appearance as quite distinctive and enough to prove its presence without any further examination. You will thus see that $I$ have lived during all the occasions of the cholera's invasion of England.

Last, and not least, the document ends by saying: " $\mathrm{My}$ Lords propose to offer you a fee of $£ 100$ for the assistance requested of you." Such an offer is so unusual that it must have been at the instigation of Sir John Simon who considered that his medical brethren should not do work for nothing.

Hampstead, Sept. 25th, 1909. I am, Sir, yours faithfully, SAMUEL WILKS.

\section{THE NATURE OF ANGINA PECTORIS.}

\section{To the Editor of THE LANCET.}

SIR,-Dr. Beddard's letter in your issue of Sept. 18th on angina pectoris in cases of mitral disease-I will not limit it to mitral "stenosis"-is very interesting to me. I am not sure whether I have or have not mentioned these cases in print, but I think I referred to them in my Mount Vernon address. At Belfast the necessarily shorter time at my disposal determined me to omit them, lest I should, really or apparently, obscure the main principles of causation.

These mitral cases, if we exclude cases of mixed or dubious nature, are exceedingly rare ; so few as to present inadequate data for argument. They are absolutely so rare that $I$ have notes of but two cases only among my own observations (neither with necropsies), and I have not been able to collect any definite addition to them from published records ; for, as I need not say, the diagnosis must be unequivocal. I have been surprised indeed to find even distinguished clinical observers using the name "angina pectoris" indiscriminately-e.g., for anxious cardiac oppressions, or for agonising paroxysms of dyspncea, such as those of high blood pressure so admirably described afresh in a recent paper by Professor Pal, and so on

Meanwhile, I think we must suspend our judgment about these notable cases, as being exceptional. In one of my cases, attended with sudden onset of mitral regurgitation, there was some reason to suspect a mixed causation. In the somewhat frequent syphilitic angina pectoris a double lesion may of course be suspected. I hope, with Dr. Beddard's assistance, to add to our evidence on this part of the subject. I am, Sir, yours faithfully,

Cambridge, Sept. 24th, 1909. ClifFORD AlLBUtT.

\section{ABSCESS OF THE BRAIN IN ASSOCIATION WITH PULMONARY DISEASE.}

\section{To the Editor of THE LANCET.}

SIR,-I have read with great interest the collection of cases in the late Dr. Schorstein's lecture on the connexion between pulmonary disease and cerebral abscess, the point which particularly interests me being the absence of tubercle ba silli in the pulmonary lesions. I venture to draw attention to the following case in connexion with the pulmonary, and possibly the cerebral, lesion in some of Dr. Schorstein's series :-

X.Y. was sent to hospital in China in 1904 or 1905 for pulmonary tuberculosis. He had syphilis two years before, but only attended regularly for treatment three months. His present illness started with symptoms of peripheral neuritis which cleared up under strychnine, massage, and electricity. His chest then became involved and he was sent to hospital. He had been in hospital some time when I saw him in con. sultation. He was thin and had an evening rise of tempera. ture with incomplete morning remission. He spat up a good deal of muco-purulent sputum which was examined for tubercle bacilli several times with negative result. There were signs of fairly extensive consolidation and some cavity formation at the right base behind. The case looked like a tuberculous broncho-pneumonia which was going downhill.

The case was considered to be syphilitic because of $(a)$ absence of tubercle bacilli in the sputum; $(\beta)$ presence of signs of active syphilis on him-i.e., an ill-defined scattered rash, and coppery scars on the legs, for which he had had insufficient treatment; $(\gamma)$ the lesion being at the base of the lung and the peripheral neuritis preceding it. The man was treated by mercurial inunctions, increasing doses of iodide of potassium, and anti-tuberculous hygiene and feeding. He got quite well and returned to his ship to duty, though there was, as would be expected, some diminished air entry at the right base behind.

The case struck me very much, as I had been looking for one for some time. I think they are likely to be more numerous ashore as the patient very often attends the doctor (not his family doctor) or the hospital for his original syphilis only as long as he has symptoms. Hence the predisposing cause, insufficient treatment. It would be of some interest if Wassermann's reaction and the effect of antisyphilitic treatment were tried in cases showing persistent absence of the tubercle bacilli from the sputum together with well-marked physical signs in the lungs. This could easily be done in an institution such as the Brompton Hospital. I believe $I$ have seen other cases of this nature published, but cannot recall them.-I am, Sir, yours faithfully,

\section{DOMICILIARY MEDICAL TREATMENT UNDER THE POOR-LAW.}

M. New Zealand, Home Fleet, Sept. 21st, 1909

$$
\text { L. LINDOP, }
$$$$
\text { taff-Surgeon, R.N. }
$$

\section{To the Editor of THE LANCET.}

SIR,-Considerations of space and some diffidence in criticising a man of Dr. Major Greenwood's experience and standing were the reasons for which I contented myself with uttering a protest against the sweeping affirmations made by him in his article in your issue of Sept. 4th. At the same time $I$ did give two most cogent reasons against his opinion that practically the whole of the lower middle and working classes would be treated gratuitously if the recommendations of the "Minority Report" were adopted. If Dr. Major Greenwood will do me the honour to read my letter again, he will see that these reasons were $: 1$. That the duty of recovering the whole or part of the cost from those able to pay would be imposed on the authorities. Since at the present time nearly $£ 300,000$ annually are recovered by the authorities for the maintenance of children in industrial schools, of children in deaf-and-dumb schools, of inmates of asylums, and of paupers it is quite reasonable and probable to suppose that the same success would attend the above procedure. 2. That since those medically attended by the authorities would not be able to choose their own doctors, and since tastes differ, it is again reasonable to suppose that the whole of the lower middle class and the better off of the working class will still in the majority of cases seek a doctor of their own choosing. Surely these reasons are not mere negations. I am, Sir, yours faithfully,

London, W., Sept. 26th, 1909.

H. BECKETT-OveRY.

\section{THE DIAGNOSIS OF FEVERS IN RANGOON. \\ To the Editor of THE LANCET.}

SIR,--Permit me to correct a statement by LieutenantColonel J. R. Forrest, R.A.M.C., in a paper he read before the Society of Tropical Medicine and Hygiene on July 16th, and published in THE LANOET on July 24th, p. 229. Lieutenant-Colonel Forrest is reported to have stated : "In Rangoon they had not yet emerged far from the period when every case of fever was returned under one of three headings," \&c. Lieutenant-Colonel Forrest, R.A.M.C., evidently only means by the term "they" officers 
in charge of British troops or cantonments, as it is evident he obtained his experience only from this source. Inquiry by him, when he was in Burma, would have revealed the fact that for the past nine years to my knowledge fevers have been carefully investigated at the Civil General Hospital, Rangoon. Numerous papers on the subject of obscure fevers had been read at monthly meetings of the British Medical Association. I am also well aware that not only in Rangoon has the diagnosis of fevers been investigated by the aid of a clinical pathological department, and that considerable interest has been roused throughout the civil surgeoncies of this province for many years past. I therefore cannot allow LieutenantOolonel Forrest's reported misleading statement to pass, and can only conclude that he is referring only to the methods of station hospitals. - I am, Sir, yours faithfully,

Rangoon, Sept. 4th, 1909.

E. R. Rost, Major, I. M.S.

\section{THE EXHIBITION OF QUININE.}

To the Editor of THE LANCET.

SIR,-A firm believer in quinine in the prophylaxis and treatment of malaria, I have been, as I suppose many others practising in the tropics have, surprised from time to time to see a man taken ill with malaria while using prophylactic quinine or a pyrexia resist full doses of the drug.

Everyone in the tropics carries his own medicine chest, and in 99 per cent. of cases he has been prescribing for himself quinine in the form of tablets, often the sugar-coated variety, or some similar preparation, and herein lies the fault. When the gastro-intestinal catarrh commonly associated with malaria is taken into account, I have little hesitation in saying that the dose of quinine it is desired to bring into action in the blood bears often no relation to the number of tablets, for instance, swallowed. I am equally convinced that much of the "upsetting of the stomach" complained of by persons taking quinine is due to the drug being taken in these forms. There can be no doubt that the only effective method of exhibiting quinine by mouth and that causing least ill-effects is as a solution. For this reason sugar-coated tablets should cease to appear on the market and only such salts of quinine as are easily soluble in water should be made up in these forms. Would it be too great an assumption of the rôle of the physician on the part of manufacturing chemists to give directions on the label that quinine tablets should be dissolved in water before being administered?

\section{I am, Sir, yours faithfully}

Hugh S. StanNus, M.B. Lond. Medical Officer, Nyasaland Administration.

\section{DARK-GROUND ILLUMINATION FOR BACTERIOLOGICAL MICROSCOPY. To the Editor of THE LANCET.}

SIR,-Having read the interesting communications by $\mathrm{Mr}$. H. Wansey Bayly and Mr. Shillington Scales in your issues of Sept. 11th, p. 782, and Sept. 18th, pp. 889-90, relative to the use of dark-ground illumination in the observation of living bacteria, \&c., I should like to be allowed to add a few remarks. It is generally understood that the source of light required must be much more intense than is ordinarily used in microscopical work; in fact, the makers all recommend a strong light. At first I employed the small arc lamp made by Leitz in conjunction with his dark-ground condenser when searching for spirochætæ and bacilli, but found it advantageous to reduce the intensity of the light by interposing screens. Afterwards I discarded the arc lamp for the Nernst electric lamp, and eventually, for the incandescent gas lamp, the weaker light being more pleasant to the eyes and giving a better contrast between the brightly illuminated objects and the dark background. During the last few weeks I have been using the recently improved reflecting condenser by Leitz, which absorbs less light than his first model, and in consequence I have reduced the strength of my light to the ordinary microscope oil lamp with simple bull's eye lens, and the results are certainly surprising. Spirochætæ and typhoid bacilli, for example, are distinctly shown against a perfectly black background, and the light being less injurious to the eyes I was able to work continuously for several hours without feeling the usual fatigue which follows the use of strong illuminants.
The fact that so weak a light as an oil lamp can be used satisfactorily in this mode of illumination may not be so highly appreciated by those at home as workers abroad, especially in regions where such commodities as gas and electricity are not to be found. Several workers in tropical medicine whom I have met were obliged to give up the idea of adopting this mode of illumination because of the impossibility of getting a sufficiently strong source of light. I am, Sir, your faithfully,

Crouch End, N., Sept. 20th, 1909. J. W. OGILYY, F.R.M.S.

\section{DIAGNOSIS IN THE GYMNASIUM.}

\section{To the Editor of THE LANCET.}

SIR,--This morning I was consulted by a young lady with lateral curvature of the spine: she had previously been advised by her family medical man to put herself under Sandow's treatment; so she was examined by Sandow who promised to cure her for 80 guineas. The parents could not afford this amount, so they decided to consult me.

Yesterday a father and mother brought me three sons who had recently been examined by Sandow; the latter said that one had serious disease of the spine and another serious heart disease without any ground for such diagnoses.

You must agree with me that it is bad enough to see Sandow's costly advertisements in the daily press, but it is worse when general practitioners stultify themselves by sending their patients direct to him.

I am, Sir, yours faithfully,

Harley-street, W., Sept. 24th, 1909. BERNARD ROTH.

\section{THE HYPNOTIC TREATMENT OF MORPHINISM.}

7o the Eator of THE LANCET.

SIR,-The problems considered by the recent International Congress on Alcoholism in London are of world-wide importance, and the British Government showed a far-seeing comprehension of the needs of the times by inviting the principal Governments of Europe and America to send to this Congress their official representatives. Nothing but good can come from such a convention in which are assembled the most distinguished scholars and ablest specialists from the foremost nations of the world.

Among the drugs that enslave, the two with which the physicians of the United States are especially concerned are alcohol and morphine. While alcoholic intoxication is an ancient and well-understood condition, morphinism is a modern disease and has not received the attention from the medical profession which it deserves. It was almost unknown in the United States before the invention of the hypodermic syringe about 50 years ago, but now it has spread through that and other nations till it has become a world-wide menace to mankind. Unlike alcoholism, morphinism is not a social vice. It flourishes alone and in the dark. Unsuspected by the victim and unknown to his friends morphine quietly and insidiously becomes master and owner of the patient's brain and nerves, and steadily month by month drags him down to mental incapacity and to physical ruin. From first to last the rictim of morphinism is in perpetual slavery. He does not have a day or a week of bondage, followed by a period of freedom, as is usually the case with alcoholics. Every day in the week and every week in the year the morphine yoke bears heavily upon him and escape is impossible without medical aid. As physicians well know, morphine cannot be denied an addict for 24 hours without causing great suffering, and after 48 hours of abstinence the agony is beyond the power of human nature voluntarily to endure. Neither is harmless moderation possible. If this drug is used daily, even in very small doses, the patient soon becomes a helpless slave to it. Morphinism is not a mere habit, but is a serious pathological condition. The will cannot be invoked for its cure as it is a disease in which the will is not a factor. It is as absurd to ask an addict to stop the use of morphine as to ask him to amputate his own arm. He can be cured only by a thorough course of sanatorium treatment. All other methods are a delusion and a snare.

The morphine addict could easily be cured, in fact, he could cure himself if it were not for the extreme suffering caused by depriving him of the drug. These withdrawal pains are so great that he is naturally willing to resort to the 